\title{
Epiphora as a side effect of topical mitomycin C
}

\section{E Dafgård Kopp, S Seregard}

Aim: To report symptoms and findings of lacrimal duct malfunction after topical mitomycin $C(M M C)$ for conjunctival neoplasia.

Methods: 14 consecutive patients treated with 1-6 cycles of topical $0.04 \%$ MMC four times daily for periods of 2 weeks were interviewed about symptoms of lacrimal duct malfunction. Patients who complained of tearing had examination of the puncta and canaliculi including probing and lacrimal duct irrigation.

Results: Nine patients complained of epiphora after topical MMC. Three of these patients had normal puncta and canaliculi, patent to irrigation. In these patients epiphora ceased spontaneously after probing and irrigation. The additional six patients had stenosis of the punctum $(n=3)$, the common canaliculus $(n=1)$, both puncta and both canaliculi $(n=1)$ and complete occlusion of the lower canaliculus $(n=1)$. Conclusion: Obstruction of the puncta or canaliculi is not an infrequent event after topical $0.04 \%$ MMC.

M itomycin C (MMC) is a chemotherapeutic antibiotic isolated from the broth of Streptomyces caespitosus. Its mode of action mimics that of ionising radiation. Cross linkage of the DNA base pairs adenine and guanine inhibits DNA synthesis in all phases of the cell cycle. Mitomycin C also causes breakage of single stranded DNA. Although its action is non-cell cycle specific, rapidly dividing cells are preferentially sensitive to these effects.

It has been used as an adjunct to glaucoma surgery ${ }^{1}$ and to prevent recurrence after pterygium surgery. Several groups have reported effectiveness of topical mitomycin $C$ in the treatment of conjunctival corneal intraepithelial neoplasia (CCIN), ${ }^{2-5}$ squamous cell carcinoma (SCC), ${ }^{67}$ and in the treatment of primary acquired melanosis (PAM $)^{8-10}$ and as an adjuvant therapy for conjunctival melanoma.9 1112

Acquired lacrimal canalicular obstruction is uncommon and has been documented to occur after viral infections (herpes simplex ${ }^{13}$ and herpes zoster ${ }^{14}$ ), local irradiation, ${ }^{15}$ and trachoma and, more frequently, after trauma. ${ }^{16}$ Lacrimal obstruction may also occur as a part of a more widespread cicatrising process, described as drug induced pemphigoid. Some topical ocular medications may cause lacrimal stenosis or occlusion after a relatively short term exposure. ${ }^{17}$ Systemic antineoplastic agents such as 5-fluorouracil may lead to punctual and canalicular stenosis. ${ }^{18}{ }^{19}$ More recently, doxetaxel (Taxotere. Aventis Pharma) is reported to be associated with a blockage of the lacrimal drainage apparatus. ${ }^{20}$

Only one case of punctal canalicular stenosis associated with MMC has been reported..$^{21}$ We present a retrospective study of patients who had received topical MMC and the effect of the lacrimal system.

\section{PATIENTS AND METHODS}

The records of all patients who received topical MMC for conjunctival neoplasia during 2000-3 in St Erik's Eye
Hospital were reviewed. If the patients complained of tearing in the treated eye at 1 month after MMC treatment, inspection of the puncta, probing, and lacrimal irrigation was performed. Fifteen patients received topical 0.04\% mitomycin C. One of these patients had punctal plugs inserted throughout treatment and was excluded from further study. The remaining 10 men and four women were 44-85 years of age (mean 62 years) and received 1-6 (mean 2.6) cycles of topical chemotherapy. Before treatment, all patients had their diagnosis confirmed by histopathological examination of excised tissue.

Briefly, 12 patients had conjunctival melanoma initially managed by surgical excision, cryotherapy to margins, and amniotic membrane transplantation; however, four of these patients had unclear surgical margins and eight patients had widespread PAM. One patient had extensive PAM with atypia not amenable to complete surgical excision and one patient had recurrent SCC of the conjunctiva and cornea.

The treatment regimen was MMC eye drops, $0.04 \%$, four times daily for a cycle of 2 weeks. If the patients had local irritations, ointment of oxytetracycline hydrocorticonacetate with polymyxin B (Terra-Cortril with polymyxin B, Pfizer) was added.

\section{RESULTS}

At the interview 1 month after completion of topical MMC, 9/14 patients complained of epiphora of the treated eye. All patients declined a previous history of epiphora or tearing of either eye (table 1). In three patients with epiphora (patients $1-3)$ the external examination of the puncta was normal and the lacrimal system was patent. After probing and syringing the epiphora ceased spontaneously. In a further three patients there was a punctal stenosis with a thin membrane covering the puncta (patients 7-9). In one patient, tearing ceased after probing (patient 7) but the other two patients with punctal stenosis required silicon intubation for 2 months (patients 8,9). Involvement of the canaliculi was observed in three patients. Patient 4 had a toxoallergic reaction of the MMC treatment with stenosis of the common canaliculus. The symptoms of epiphora ceased after 4 months of silicon intubation. Patient 6 had previously received five cycles of MMC before she was referred to our clinic. She had stenosis of both puncta and of the lower and upper canaliculi. She declined additional surgery. Patient 5 had no symptoms after two MMC cycles, but experienced complete obstruction of the lower canaliculus $2 \mathrm{~mm}$ from punctum after the third cycle. The upper canaliculus remained patent and tearing stopped after approximately 6 months.

The number of cycles did not seem to correlate with epiphora. Three patients received 4-6 MMC cycles and did not experience epiphora.

Abbreviations: CCIN, conjunctival corneal intraepithelial neoplasia; $M M C$, mitomycin C; PAM, primary acquired melanosis; SCC, squamous cell carcinoma 
Table 1 Detailed information on 14 patients with topical MMC treatment

\begin{tabular}{|c|c|c|c|c|c|c|c|c|}
\hline Patient & Sex/age & Diagnosis & $\begin{array}{l}\text { No of } \\
\text { cycles }\end{array}$ & Epiphora & Lacrimal system findings & Other signs & Treatment & Outcome \\
\hline 1 & $M / 49$ & $M M+P A M$ & 3 & Yes & Normal anatomy & & $\begin{array}{l}\text { Probing and } \\
\text { syringing }\end{array}$ & Patent \\
\hline 2 & $M / 75$ & $M M+P A M$ & 1 & Yes & Normal anatomy & & $\begin{array}{l}\text { Probing and } \\
\text { syringing }\end{array}$ & Patent \\
\hline 3 & $M / 83$ & $M M+P A M$ & 2 & Yes & Normal anatomy & & $\begin{array}{l}\text { Probing and } \\
\text { syringing }\end{array}$ & Patent \\
\hline 4 & $M / 44$ & $M M+P A M$ & 1 & Yes & $\begin{array}{l}\text { Common canalicular } \\
\text { stenosis }\end{array}$ & $\begin{array}{l}\text { Toxoallergic } \\
\text { reaction }\end{array}$ & $\begin{array}{l}\text { Silicon intubation } \\
4 \text { months }\end{array}$ & Patent \\
\hline 5 & $M / 47$ & $M M+P A M$ & 3 & Yes & $\begin{array}{l}\text { Lower canalicular } \\
\text { obstruction }\end{array}$ & & None & $\begin{array}{l}\text { Patent upper } \\
\text { canaliculus }\end{array}$ \\
\hline 6 & $\mathrm{~F} / 52$ & $M M+P A M$ & 5 & Yes & $\begin{array}{l}\text { Punctum and canalicular } \\
\text { stenosis }\end{array}$ & & None & Watering \\
\hline 7 & $M / 56$ & $M M$ & 1 & Yes & Punctum stenosis & & $\begin{array}{l}\text { Probing and } \\
\text { syringing }\end{array}$ & Patent \\
\hline 8 & $M / 71$ & $M M$ & 2 & Yes & Punctum stenosis & & $\begin{array}{l}\text { Silicon intubation } \\
2 \text { months }\end{array}$ & Patent \\
\hline 9 & $F / 63$ & $M M$ & 1 & Yes & Punctum stenosis & & $\begin{array}{l}\text { Silicon intubation } \\
2 \text { months }\end{array}$ & Patent \\
\hline 10 & $M / 62$ & $M M+P A M$ & 4 & No & & $\begin{array}{l}\text { Toxoallergic } \\
\text { reaction }\end{array}$ & & \\
\hline 11 & $\mathrm{~F} / 51$ & PAM & 6 & No & & & & \\
\hline 12 & $M / 80$ & $M M$ & 1 & No & & & & \\
\hline 13 & $M / 49$ & SCC & 5 & No & & & & \\
\hline 14 & $F / 85$ & $M M+P A M$ & 1 & No & & & & \\
\hline
\end{tabular}

\section{DISCUSSION}

The preferred management of ocular surface neoplasia is controversial. Complete surgical excision of the lesion is the most commonly accepted method of treatment. ${ }^{22}$ Adjuvant techniques like cryotherapy and topical chemotherapy are often required as the lesions may be diffuse and recurrence rates are high. The use of topical MMC has a significant value in the treatment of $\mathrm{CCIN}^{2-5}$ and PAM with atypia. ${ }^{8-10}$ It is also used following excision and cryotherapy in these entities and in conjunctival melanoma.

Topical MMC $0.04 \%$ is relatively non-toxic to an intact epithelium. Side effects includes conjunctival injection, photophobia, pain, punctuate epithelial keratopathy, and blepharospasm ${ }^{2}$ When applied to bare sclera, corneal oedema and perforation, scleral ulceration, necrotising scleritis, scleral calcification, secondary glaucoma, cataract, and iritis have been described..$^{23}$

Occlusion of the lacrimal puncta by the patient following MMC application ${ }^{6}$ or using temporary punctal plugs ${ }^{24}$ have been advocated to limit toxicity to the nasolacrimal system and decrease systemic absorption.

Epiphora following topical MMC was first described in a patient who experienced a toxoallergic reaction to topical MMC and 1 month later developed complete stenosis of the lower canaliculus. ${ }^{21}$ Topical MMC was believed to cause an inflammatory response leading to secondary fibrosis and stenosis of the lacrimal duct. However, this may not be the only mechanism as only one of the nine patients with epiphora we studied had experienced a previous toxoallergic reaction. Further, there was one patient who received four cycles and finally developed a toxoallergic reaction but who did not have any problems with tearing.

Canalicular stenosis has been reported with the use of topical cyclopentolate hydrochloride, furtrethonium, and idoxuridine as a result of allergic, inflammatory reactions. Systemic administration of fluorouracil has been associated with canaliculitis, stenosis, and epiphora by causing irritation of the canaliculus and subsequent fibrosis. ${ }^{19}$ Recently, systemic doxetaxel was reported to develop canalicular stenosis ${ }^{20}$ and this side effect could be secondary to secretion of the chemotherapeutic agent in the tear film and fibrosis of the canaliculi from direct contact with the drug.
It is possible that epiphora after topical MMC is caused by non-specific inflammation causing epithelial sloughing, subepithelial fibrosis and, eventually, stenosis of the lacrimal duct. However, in some cases probing and syringing of the puncta may be sufficient for epiphora to cease. This suggests that cellular debris sometimes may form a membrane which occludes the puncta without involving significant fibrosis. Interestingly, the antiproliferative effect of MMC is believed to prevent fibrosis and prevent long term patency of the lacrimal drainage system when applied to osteotomy sites in dacryocystorhinostomies ${ }^{25}$ and, when used as an adjuvant to punctoplasty, to prevent punctual re-stenosis. ${ }^{26}$ Conversely, our findings suggest that MMC may cause significant ocular inflammation and induce fibrosis. To prevent this, punctal plugs could be used. These are relatively inexpensive and probably effective in reducing exposure of the lacrimal apparatus to topical MMC when used for ocular surface disease.

\section{Authors' affiliations}

E Dafgård Kopp, S Seregard, St Erik's Eye Hospital, Karolinska Institutet, Polhemsgatan 50, S-112 82 Stockholm, Sweden

Correspondence to: Eva Dafgård Kopp, St Erik's Eye Hospital, Karolinska Institutet, Polhemsgatan 50, S-112 82 Stockholm, Sweden; eva.dafgard@sankterik.se

Accepted for publication 16 May 2004

\section{REFERENCES}

1 Palmer SS. Mitomycin as adjunct chemotherapy with trabeculectomy Ophthalmology 1991;98:317-21.

2 Wilson MW, Hungerford JL, George SM, et al. Topical mitomycin C for the treatment of conjunctival and corneal epithelial dysplasia and neoplasia. Am J Ophthalmol 1997; 124:303-11

3 Heigle TJ, Stulting RD, Palay DA. Treatment of recurrent conjunctival epithelial neoplasia with topical mitomycin C. Am J Ophthalmol 1997;124:397-9.

4 Frucht-Pery J, Sugar J, Baum J, et al. Mitomycin C treatment for conjunctivalcorneal intraepithelial neoplasia: a multicenter experience. Ophthalmology 1997; 104:2085-93.

5 Frucht-Pery J, Rozenman Y. Mitomycin C therapy for corneal intraepithelial neoplasia. Am J Ophthalmol 1994;117:164-8.

6 Shields CL, Naseripour M, Shields JA. Topical mitomycin C for extensive, recurrent conjunctival-corneal squamous cell carcinoma. Am J Ophthalmol 2002; 133:601-6. 
7 Frucht-Pery J, Rozenman Y, Pe'er J. Topical mitomycin-C for partially excised conjunctival squamous cell carcinoma. Ophthalmology 2002;109:548-52.

8 Frucht-Pery J, Pe'er J. Use of mitomycin C in the treatment of conjunctival primary acquired melanosis with atypia. Arch Ophthalmo 1996; 114:1261-4.

9 Finger PT, Czechonska G, Liarikos S. Topical mitomycin C chemotherapy for conjunctival melanoma and PAM with atypia. $\mathrm{Br} J$ Ophthalmol 1998:82:476-9.

10 Rodriguez-Ares T, Tourino R, De Rojas V, et al. Topical mitomycin C in the treatment of pigmented conjunctival lesions. Cornea 2003;22:1 14-7.

11 Finger PT, Milner MS, McCormick SA. Topical chemotherapy for conjunctival melanoma. Br J Ophthalmol 1993;77:751-3.

12 Shields CL, Shields JA, Armstrong T. Management of conjunctival and corneal melanoma with surgical excision, amniotic membrane allograft, and topical chemotherapy. Am J Ophthalmol 2001;132:576-8.

13 Coster DJ, Welham RA. Herpetic canalicular obstruction. Br J Ophthalmol 1979;63:259-62.

14 Sanke RF, Welham RA. Lacrimal canalicular obstruction following chickenpox. Br J Ophthalmol 1982;66:71-4.

15 Call NB, Welham RA. Epiphora after irradiation of medial eyelid tumors. Am J Ophthalmol 1981;92:842-5.

16 Rose GE, Welham RA. Jones' lacrimal canalicular bypass tubes: twenty-five years' experience. Eye 1991;5(Pt 1):13-9.
17 McNab AA. Lacrimal canalicular obstruction associated with topical ocular medication. Aust N Z J Ophthalmol 1998;26:219-23.

18 Caravella LP Jr, Burns JA, Zangmeister M. Punctal-canalicular stenosis related to systemic fluorouracil therapy. Arch Ophthalmol 1981;99:284-6.

19 Brink HM, Beex LV. Punctal and canalicular stenosis associated with systemic fluorouracil therapy. Report of five cases and review of the literature. Doc Ophthalmol 1995;90:1-6.

20 Esmaeli B, Valero V, Ahmadi MA, et al. Canalicular stenosis secondary to docetaxel (Taxotere): a newly recognized side effect. Ophthalmology 2001; 108:994-5.

21 Billing K, Karagiannis A, Selva D. Punctal-canalicular stenosis associated with mitomycin-C for corneal epithelial dysplasia. Am J Ophthalmol 2003;136:746-7

22 Shields JA, Shields CL, De Potter P. Surgical management of conjunctival tumors. The 1994 Lynn B. McMahan Lecture. Arch Ophthalmol 1997; 115:808-15

23 Rubinfeld RS, Pfister RR, Stein RM, et al. Serious complications of topical mitomycin-C after pterygium surgery. Ophthalmology 1992;99:1647-54.

24 Grossniklaus HE, Aaberg TM Sr. Mitomycin C treatment of conjunctival intraepithelial neoplasia. Am J Ophthalmol 1997;124:381-3.

25 Liao SL, Kao SC, Tseng JH, et al. Results of intraoperative mitomycin C application in dacryocystorhinostomy. Br J Ophthalmol 2000;84:903-6.

26 Lam S, Tessler HH. Mitomycin as adjunct therapy in correcting iatrogenic punctal stenosis. Ophthalmic Surg 1993;24:123-4. 